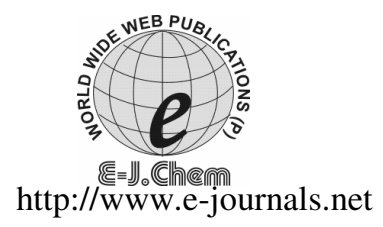

ISSN: 0973-4945; CODEN ECJHAO

E-Journal of Chemistry 2009, 6(S1), S459-S465

\title{
Simultaneous Spectrophotometric Determination of Chromium(VI) and Vanadium(V) by using 3,4-Dihydroxybenzaldehyde isonicotinoyl hydrazone (3,4-DHBINH)
}

\author{
LAKSHMI NARAYANA, SUVARAPU ${ }^{\S *}$ \\ ADINARAYANA REDDY SOMALA, PRATHIMA BOBBALA, \\ HWANG INSEONG ${ }^{\S}$, VARADA REDDY AMMIREDDY \\ ${ }^{\S}$ School of Civil and Environmental Engineering, \\ Pusan National University, Busan-609 735, Korea. \\ Analytical Division, Department of Chemistry, \\ S.V. University, Tirupati-517 502, India. \\ lakshminarayana_chem@rediffmail.com
}

Received 5 June 2009; Accepted 3 August 2009

\begin{abstract}
A simple, rapid, highly sensitive and new simultaneous spectrophotometric method is proposed for the analysis of chromium(VI) and vanadium(V) without separation by using 3,4-dihydroxybeznaldehyde isonicotinoyl hydrazone (3,4-DHBINH). The reagent reacts with the two metal ions in acetic acid-sodium acetate buffer of $\mathrm{pH} 5.5$ and gives maximum absorbances at $400 \mathrm{~nm}$ and $360 \mathrm{~nm}$ for chromium(VI) and vanadium(V), respectively. Both the metal ions gives 1: 1 (M:L) complexes with the reagent. Effect of various diverse ions also studied. The instability constants for the two complexes were also evaluated. This method was successfully applied for the determination of chromium(VI) and vanadium(V) in various spiked samples. The validity of the method was checked by comparing with the results obtained by atomic absorption spectrophotometry.
\end{abstract}

Keywords: Vanadium(V), Chromium(VI), 3,4-Dihydroxybenzaldehyde isonicotinoyl hydrazone,

\section{Introduction}

Chromium exist in natural water in two stable oxidation states, $\mathrm{Cr}(\mathrm{III})$ and $\mathrm{Cr}(\mathrm{VI})$. Among these two predominant forms, $\mathrm{Cr}$ (III) is considered to be essential to mammals for the maintenance of glucose, lipid and protein metabolism, where as $\operatorname{Cr}(\mathrm{VI})$ is a toxic and 
carcinogenic form ${ }^{1-3}$. Chromium compounds that are inhaled have been linked with lung cancer, while those ingested can cause kidney and liver damage ${ }^{4}$.

It is known that an increase in the content of chromium in soils makes them infertile and that the toxic effect depends on the oxidation state of chromium. On the other hand, the introduction of chromium salts into soils have been some positive effects due to activation of some bio-chemical processes ${ }^{5}$. $\mathrm{Cr}(\mathrm{VI})$ compounds toxicity derives from its ability to diffuse through cell membrane and oxidize biological molecules ${ }^{6}$.

Because of the above reasons the determination of chromium in environmental and biological samples is of great interest. Determination of $\mathrm{Cr}(\mathrm{VI})$ in micro quantities is of interest to analytical chemists. Although AAS is the most common method of chromium detection. Besides AAS, number of other methods have been reported for $\mathrm{Cr}(\mathrm{VI})$ determination such as NAA, ICP-MS, ICP-AES ${ }^{7-9}$. Moreover, such techniques are usually not available in most laboratories. Because of expensive cost of the above instruments most of the researchers are still interested in colorimetric and spectrophotometric methods ${ }^{10-13}$.

A numerous reagents were reported for the spectrophotometric determination of $\mathrm{Cr}(\mathrm{VI})$ and $\mathrm{V}(\mathrm{V})^{14-28}$. However, the mutual interferences of these two ions make very difficult for the simultaneous determination.

The present paper describes a highly sensitive, simple, inexpensive and comparable selective method for the direct simultaneous spectrophotometric determination of $\mathrm{Cr}(\mathrm{VI})$ and $\mathrm{V}(\mathrm{V})$ without separation by using 3,4-dihydroxybenzaldehyde isonicotinoyl hydrazone (3,4DHBINH). The present method has been applied for the determination of $\mathrm{Cr}(\mathrm{VI})$ and $\mathrm{V}(\mathrm{V})$ in various spiked samples.

\section{Experimental}

\section{Preparation of 3,4-Dihydroxybenzaldehyde isonicotinoyl hydrazone ${ }^{29}$}

Equimolar quantities of 3,4-dihydroxybenzaldehyde (dissolved in alcohol) and isonicotinichydrazide (dissolved in water) were taken in a $500 \mathrm{~mL}$ round bottom flask and refluxed for 2-3 h. The contents were cooled and then filtered. The product (Scheme 1) obtained was washed with aqueous methanol and finally recrystallized from rectified spirit. The purity of the reagent was checked by TLC and melting point analysis (m.p. $\left.218-219^{0} \mathrm{C}\right)$.

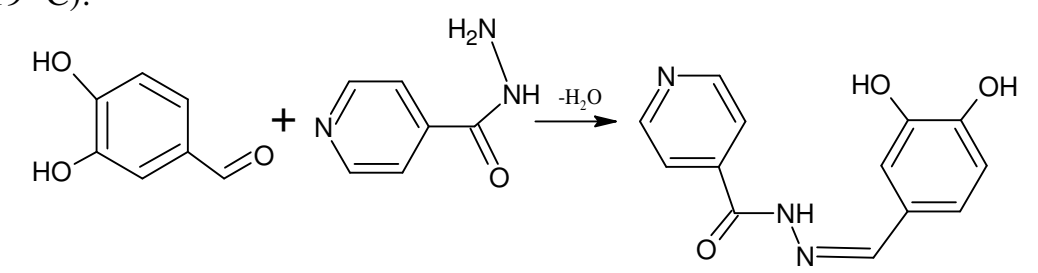

3,4-Dihydroxybenzaldehyde

Isonicotinic hydrazide 3,4-Dihydroxybenzaldehyde isonicotinoyl hydrazone

Scheme 1. Formation of 3, 4-DHBINH.

It is evident from IR spectrum (Figure 1) that, $\mathrm{C}=\mathrm{N}$ group is present in the compound because the peak appears at $1600 \mathrm{~cm}^{-1} . \mathrm{C}=\mathrm{O}$ (Stretching) amide peak appears at $1656.9 \mathrm{~cm}^{-1}$.-OH group peak appears at $3484.6 \mathrm{~cm}^{-1}$, -NH peak appears at $3245 \mathrm{~cm}^{-1}$. From the above data it is confirmed the formation of 3,4-dihydroxybenzaldehydeisonicotinoylhdrazone. A $0.1 \mathrm{~mol} \mathrm{~L}^{-1}$ stock solution was prepared by dissolving $2.57 \mathrm{~g}$ of 3,4-DHBINH in $40 \%$ aqueous dimethyl formamide(DMF). 


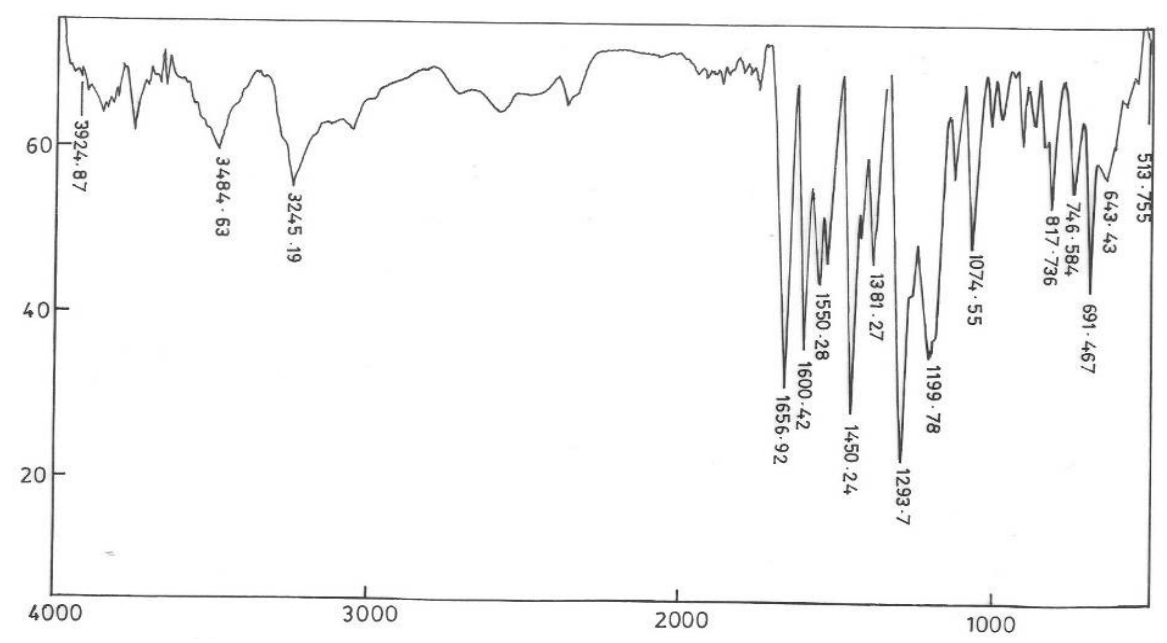

Figure 1 IR spectrum of 3, 4-Dihydroxybenzaldehyde isonicotinoyl hydrazone.

\section{Preparation of a stock solution of chromium(VI)}

Stock solution $\left(1180 \mu \mathrm{g} \cdot \mathrm{mL}^{-1}\right.$ of $\left.\mathrm{Cr}(\mathrm{VI})\right)$ was prepared by dissolving potassiumdichromate (99.9\% pure ,Glaxo) in de-ionized water. The remaining solutions were prepared by appropriate dilutions of the standard.

\section{Preparation of a stock solution of vanadium $(V)$}

The stock solution $\left(1.0 \times 10^{-2} \mathrm{~mol} \mathrm{~L} \mathrm{~L}^{-1}\right)$ was prepared by dissolving $1.17 \mathrm{~g}$ of ammonium metavanadate in one litre of double distilled water and standardized by the iron(II) method ${ }^{30}$ volumetrically. Lower concentrations of the metal ion are obtained by suitable dilution of the stock solution.

\section{Apparatus}

A recording spectrophotometer (model Hitachi U-2000) was employed in photometric studies. A Perkin-Elmer 2380 atomic absorption spectro- photometer was employed for the comparison of the results of samples. A digital pH meter (model Elico LI -129) was used for measuring the $\mathrm{pH}$ of solutions.

\section{Buffer solutions}

Solutions of $1.0 \mathrm{~mol} \mathrm{~L}^{-1}$ sodium acetate and $1.0 \mathrm{~mol} \mathrm{~L}^{-1}$ acetic acid were prepared in double distilled water. Suitable portions of these solutions were mixed to get the desired $\mathrm{pH}$ of the solution.

\section{Results and Discussion}

\section{Absorption spectra}

The absorption spectra of $\mathrm{V}(\mathrm{V})-3,4-\mathrm{DHBINH}$ and $\mathrm{Cr}(\mathrm{VI})-3,4-\mathrm{DHBINH}$ complex was recorded against the reagent blank. Similarly the absorption spectrum of the reagent (3,4-DHBINH) was recorded against solvent blank. The absorption spectra of both the complexes and reagent were shown in (Figure 2). From the absorption spectra it is clear that the $\mathrm{V}(\mathrm{V})-3,4-\mathrm{DHBINH}$ and $\mathrm{Cr}(\mathrm{VI})-3,4-\mathrm{DHBINH}$ complexes and reagent have shown maximum absorptions at $360 \mathrm{~nm}, 400 \mathrm{~nm}$ and $340 \mathrm{~nm}$, respectively. The reagent has minimum absorbance at the maximum absorbance of the complexes. The reagent absorbance 
at the maximum absorbance of metal complexes was further suppressed using suitable concentration of reagent as blank and further absorbance measurements were made at 360 $\mathrm{nm}$ for $\mathrm{V}(\mathrm{V})$ complex and at $400 \mathrm{~nm}$ for $\mathrm{Cr}(\mathrm{VI})$ complex.

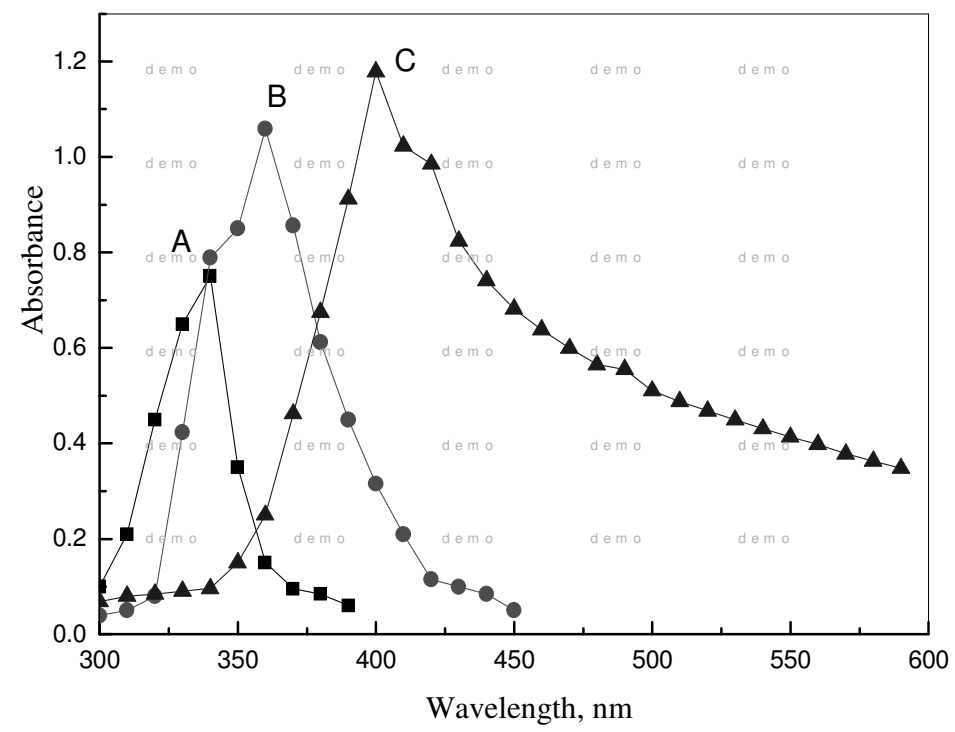

Figure 2. (A) Absorbance spectra of 3,4-DHBINH vs. blank, (B) Absorbance spectra of $\mathrm{V}(\mathrm{V})-3,4-\mathrm{DHBINH}$ complex vs. reagent. (C) Absorbance spectra of $\mathrm{Cr}(\mathrm{VI})-3,4-\mathrm{DHBINH}$ complex vs. reagent $\mathrm{V}(\mathrm{V})=\mathrm{Cr}(\mathrm{VI})=1 \mathrm{~mL}$ of $1.0(\mathrm{x}) 10^{-4}$ mol. $\mathrm{L}^{-1} ; \mathrm{pH}: 4.0 \mathrm{~mL}$ of $5.5 ; 3,4-$ DHBINH: $1.0 \mathrm{~mL}$ of $1.0(\mathrm{x}) 10^{-3} \mathrm{~mol} . \mathrm{L}^{-1}$.

\section{Applicability of Beer's law}

Known aliquots of $10.0 \mathrm{~mL}$ solutions, each containing constant volumes of $4.0 \mathrm{~mL}$ of buffer $(\mathrm{pH}=5.5), 1.0 \mathrm{~mL}$ of $10.0 \times 10^{-4} \mathrm{~mol} \mathrm{~L}^{-1}$ reagent, $1.0 \mathrm{~mL}$ of chromium(VI) [containing 0.5 $10.0 \mu \mathrm{g} \mathrm{mL}^{-1}$ ] and $1.0 \mathrm{~mL}$ of vanadium(V) [containing $0.5-7.0 \mu \mathrm{g} \mathrm{mL}^{-1}$ ] were prepared. The absorbance of these solutions was measured at $400 \mathrm{~nm}$ for chromium(VI) complex and at $360 \mathrm{~nm}$ for vanadium(V) complex. From the graph plotted between the amount of metal ion and its absorbance can be observed that a linear plot passing through the origin obeys Beer's law in the range 0.5-7.7 $\mu \mathrm{g} \mathrm{mL}^{-1}$ of chromium(VI) and 0.5-5.3 $\mu \mathrm{g} \mathrm{mL}^{-1}$ of vanadium(V).

\section{Molar absorptivity, Sandell's sensitivity and correlation co-efficient}

The molar absorptivity and Sandell's sensitivity of $\mathrm{Cr}(\mathrm{VI})$ complex was calculated to be $1.3513 \times 10^{4} \mathrm{~L} \mathrm{~mol}^{-1} \mathrm{~cm}^{-1}$ and $0.0075 \mu \mathrm{g} . \mathrm{cm}^{-2}$, respectively. The molar absorptivity and Sandell's sensitivity of $\mathrm{V}(\mathrm{V})$ complex was calculated to be $1.29 \times 10^{4} \mathrm{~L} \mathrm{~mol}^{-1} \mathrm{~cm}^{-1}$ and $0.003949 \mu \mathrm{g} . \mathrm{cm}^{-2}$, respectively.

The correlation co-efficient of the Cr(VI)-3,4-DHBINH and V(V)-3,4-DHBINH complexes was 0.99 and 0.992 , respectively which indicate an excellent linearity between the two variables.

\section{Precision and accuracy of the method and detection limit of the method}

To assess the precision of the method, determinations were carried out with different concentrations of chromium(VI) and vanadium(V) under optimum conditions. The standard 
deviations were found to be not more than 0.0021 and 0.00158 for chromium(VI) and vanadium(V), respectively. The relative standard deviations were less than $0.728 \%$ and $0.424 \%$. It is evident from these results, that the method is precise, besides being accurate. The detection limits of chromium(VI) and vanadium(V) were found to be $0.0045 \mu \mathrm{g} \mathrm{mL}^{-1}$ and $0.01677 \mu \mathrm{g} \mathrm{mL}^{-1}$, respectively.

\section{Calculation of instability constant}

The instability constant of $\mathrm{Cr}(\mathrm{VI})-3,4-\mathrm{DHBINH}$ and $\mathrm{V}(\mathrm{V})-3,4-\mathrm{DHBINH}$ complex was calculated from the intercept value on the y-axis of Asmus' method graph and by using the following equation:

$$
\begin{aligned}
\text { Intercept } & =-\left[\mathrm{b}_{\mathrm{c}} / \mathrm{V}\right]^{\mathrm{n}} \cdot 1 / \mathrm{K}_{\mathrm{c}} \\
\text { Where } \mathrm{K}_{\mathrm{c}} & =\text { the instability constant of the complex } \\
\mathrm{b}_{\mathrm{c}} & =\text { concentration of the reagent } \\
\mathrm{V} & =\text { total volume of the final solution }
\end{aligned}
$$

The instability constant of $\mathrm{Cr}(\mathrm{VI})-3,4-\mathrm{DHBINH}$ complex and $\mathrm{V}(\mathrm{V})-3,4-\mathrm{DHBINH}$ were calculated and found to be $0.7042 \times 10^{-5}$ and $4.1666 \times 10^{-3}$, respectively at room temperature.

\section{Composition of the complexes}

Job's method of continuous variation, molar ratio method and Asmus' methods are employed to elucidate the composition of the complexes. Equimolar solutions of chromium(VI), vanadium(V) and 3,4-DHBINH $\left(1.0 \times 10^{-4} \mathrm{~mol} \mathrm{~L}^{-1}\right)$ were used to determine the metal to ligand ratio by Job's method of continuous variation. The absorbance values were recorded at $400 \mathrm{~nm}$ and $360 \mathrm{~nm}$ against the reagent blank. A plots were drawn between the absorbance and $\mathrm{V}_{\mathrm{M}} / \mathrm{V}_{\mathrm{M}}+\mathrm{V}_{\mathrm{L}}$, where $\mathrm{V}_{\mathrm{M}}$ and $\mathrm{V}_{\mathrm{L}}$ are the volumes of the reagent and metal, respectively. The obtained curves are indicative of 1:1 stoichiometry in the complex. This was further confirmed by molar-ratio method. Finally the composition of the complex was verified by Asmus's method.

\section{Effect of foreign ion in the determination of chromium(VI)}

The effect of foreign ions on complexation was studied by taking $1.0 \mathrm{~mL}$ of $\mathrm{Cr}(\mathrm{VI})$ solution, $1.0 \mathrm{~mL}$ of required concentration of the foreign ion solution, $4.0 \mathrm{~mL}$ of buffer $(\mathrm{pH}=5.5)$ and $2.0 \mathrm{~mL}$ of 3,4-DHBINH solution in a $10.0 \mathrm{~mL}$ standard flask. The total volume of the solution was brought to $10.0 \mathrm{~mL}$ with double distilled water. The experiment was repeated by changing the concentration of the diverse ion. The absorbances were measured at $400 \mathrm{~nm}$. A change of \pm 0.02 was taken as the tolerance limit for interference. The interference of various ions in the determination of chromium is reported in Table 1.

Table 1. Tolerance limit of diverse ions in the determination of chromium(VI).

\begin{tabular}{cccc}
\hline Diverse ion & $\begin{array}{c}\text { Tolerance limit, } \\
\mu \mathrm{g} \cdot \mathrm{mL}^{-1}\end{array}$ & Diverse ion & $\begin{array}{c}\text { Tolerance } \\
\text { limit, } \mu \mathrm{g} \cdot \mathrm{mL}^{-1}\end{array}$ \\
\hline Ascorbicacid, & 10000 & $\mathrm{Mg}(\mathrm{II}), \mathrm{Ca}(\mathrm{II})$ & 4000 \\
Thiocyanate & 8000 & $\mathrm{Ba}(\mathrm{II}), \mathrm{Mn}(\mathrm{II})$ & 3500 \\
Sulphate & 6000 & $\mathrm{Al}(\mathrm{III})$ & 2500 \\
Thiourea & 2500 & $\mathrm{Fe}(\mathrm{III})$ & 2000 \\
Iodide & 1000 & $\mathrm{NI}(\mathrm{II})$ & 1500 \\
Tartrate & 750 & $\mathrm{Cu}(\mathrm{II})$ & 500 \\
Oxalate & 500 & & \\
Phosphate & & & \\
\hline
\end{tabular}




\section{Applications}

The rapidity of color development with 3,4-DHBINH is an advantage in analyzing various samples, in which chromium(VI) and vanadium(V) can vary over a wide range. The proposed method has been applied for the determination of chromium(VI) and vanadium(V) in synthetic water samples. The results are in perfect agreement with those obtained by direct atomic-absorption spectrometry (AAS).

\section{Determination of chromium (VI) in synthetic water samples}

Various synthetic water samples were prepared ${ }^{31}$ and the amount of chromium present in the sample solutions were determined by applying the general procedure. The results are compared with those obtained with AAS. The results are reported in Table 2.

Table 2. Determination of chromium(VI) in water samples.

\begin{tabular}{|c|c|c|c|c|c|c|c|}
\hline Samples & $\begin{array}{l}\text { Composition of synthetic } \\
\text { samples, } \mu \mathrm{g} \cdot \mathrm{mL}^{-1}\end{array}$ & $\begin{array}{c}\text { Amo } \\
\text { Cr(VI) } \\
\text { AAS } \\
\text { method }\end{array}$ & $\begin{array}{l}\text { unt of } \\
\text { found }^{\mathrm{a}} \\
\text { Present } \\
\text { method }\end{array}$ & S.D. & $\begin{array}{l}\text { R.S. } \\
\text { D\% }\end{array}$ & t-Test & F-Test \\
\hline Sample 1 & $\begin{array}{l}\mathrm{Cr}(\mathrm{VI})-5.0 \mathrm{Fe}(\mathrm{III})-4.0 \\
\mathrm{Bi}(\mathrm{III})-3.0\end{array}$ & 4.98 & 4.92 & 0.012 & 0.248 & 4.35 & 2.02 \\
\hline Sample 2 & $\begin{array}{l}\mathrm{Cr}(\mathrm{VI})-10.0, \mathrm{Ni}(\mathrm{II})-6.0 \\
\mathrm{Mn}(\mathrm{II})-5.0\end{array}$ & 9.96 & 9.93 & 0.015 & 0.159 & 4.50 & 2.5 \\
\hline Sample 3 & $\begin{array}{l}\mathrm{Cr}(\mathrm{VI})-15.0, \mathrm{Cu}(\mathrm{II})-6.0, \\
\mathrm{Al}(\mathrm{III})-6.0\end{array}$ & 14.95 & 14.90 & 0.013 & 0.088 & 4.50 & 3.5 \\
\hline
\end{tabular}

Simultaneous determination of $C r(V I)$ and $V(V)$ in synthetic water samples

Various synthetic water samples were prepared and the amount of chromium(VI) and vanadium $(\mathrm{V})$ present in the sample solutions were determined by applying the general procedure. The results are compared with those obtained with AAS. The results are reported in Table 3.

Table 3. Simultaneous determination of chromium(VI) and vanadium(V) in synthetic mixtures.

\begin{tabular}{ccccccccc}
\hline \multirow{2}{*}{ S.No. } & \multicolumn{2}{c}{$\begin{array}{c}\text { Amount of metal } \\
\text { taken, }\end{array}$} & \multicolumn{2}{c}{$\begin{array}{c}\text { Amount of metal } \\
\text { found by AAS }\end{array}$} & \multicolumn{2}{c}{$\begin{array}{c}\text { Amount of metal found } \\
\text { by present method }\end{array}$} & \multicolumn{2}{c}{$\%$ of recovery } \\
\cline { 2 - 9 } & $\mathrm{Cr}(\mathrm{VI})$ & $\mathrm{V}(\mathrm{V})$ & $\mathrm{Cr}(\mathrm{VI})$ & $\mathrm{V}(\mathrm{V})$ & $\mathrm{Cr}(\mathrm{VI})$ & $\mathrm{V}(\mathrm{V})$ & $\mathrm{Cr}(\mathrm{VI})$ & $\mathrm{V}(\mathrm{V})$ \\
\hline Sample 1 & 2.0 & 1.25 & 1.98 & 1.24 & 1.90 & 1.20 & 95.5 & 96.7 \\
Sample 2 & 3.0 & 2.00 & 2.99 & 1.98 & 2.89 & 1.93 & 96.3 & 97.4 \\
Sample 3 & 4.0 & 2.50 & 3.98 & 2.49 & 3.95 & 2.45 & 98.3 & 98.3 \\
\hline
\end{tabular}

\section{Conclusions}

The rapidity of color development with 3,4-DHBINH is an advantage in analyzing various samples, in which chromium(VI) and vanadium(V) can vary over a wide range. When compared to the other existing methods, the developed method retains specific interaction of chromium(VI) and vanadium(V) with 3,4-DHBINH to form a colored complex and has good sensitivity at room temperature without the need of extraction. The uses of organic solvents, which are generally toxic, are avoided in this proposed method. The proposed method has significant advantage over the other spectrophotometric methods in terms of simplicity, sensitivity and free from interfering ions. This proposed method has good precision and accuracy. This method has therefore been successfully applied for the simultaneous determination of chromium(VI) and vanadium(V) synthetic water samples and the results disclosed are in good agreement with the results obtained by AAS. 


\section{Acknowledgements}

One of the authors Lakshmi Narayana Suvarapu is greatly thankful to BK 21 (Brain Korea) programme for the financial assistance in the form of Post doctoral fellowship.

\section{References}

1 Nriagu J O and Nieboer E, Chromium in the Natural and Human Environment. John Wiley and Sons, New York, 1989.

2 Turyan I and Mandler D, Anal Chem., 1997, 69, 894.

3 Stoeppler M, Hazardous Metals in the Environment Techniques and Instrumentation in Analytical Chemistry, Elsevier, Amesterdam, 1992, 373.

$4 \quad$ Prakash R, Bansal R, Kaur A and Rehani S K, Talanta, 1991, 38, 1163.

$5 \quad$ Kamburova M, Talanta, 1993, 40, 713.

6 Shaffer R E, Cross J O, Rose-Pehrsson S L and Elam W T, Anal Chim Acta, 2001, 442, 295.

7 Ressalan S, Chauhan R S, Goswami A K and Purohit D N, Rev Anal Chem., 1997, 16(2), 69.

8 Takeda K, Watanabe S, Naka H, Okuzaki J and Fujimoto T, Anal Chim Acta, 1998, 377(1), 47.

9 Satyaveni S, Preconcentration and Determination of Trace Metals by ICP-AES, Ph.D Thesis, S.V.University, India, 2007.

10 El-Shahat M A, Anal Sci., 2000, 16, 151.

11 Ahmed M J, Jahan I and Banoo S, Anal Sci., 2002, 18, 805.

12 Revanasiddappa H D and Kumar T N K, Anal Sci., 2001, 17, 1309.

13 Joseph A, Narayana B and Nambiar C H R, Anal Sci., 2000, 16, 985.

14 Kalventis E, Mikrochim Acta, 1986, 1, 27.

15 Salinal F, Benzas Nevado J T and Espinosa A, Proc Indian Acad Sci., 1986. 97,153.

16 Sharma S R and Mehtha J R, Indian J Chem., 1996, 35A, 76.

17 Dudarev V I, Dolgorev V A and Volkov A. N, Zh Analit Khim., 1986,41, 289.

18 Venkatanarayana Reddy B, 2,4-Dihydroxyacetophenoneisonicotinoylhydrazone as a complexing agent for the spectrophotometric determination of some important metal ions, Ph.D., Thesis, S. K. University, India, 2006.

19 Kalventis E, Anal Lett., 1989, 22, 2083.

20 Ogawa H, Doi K and Otomo M, Analyst, 1985, 110, 1009.

21 Agnihothri N, Dass R and Mehtha J R, J Indian Chem Soc., 1998, 75, 486.

22 Reddy V K, Reddy S M, Reddy P R and Reddy T S, J Anal Chem., 2000, 55, 435.

23 Reddy V K, Reddy S M, Chennaiah A, Raveendra Reddy P and Sreenivasulu Reddy T, J Anal Chem., 2003, 58, 442.

24 Vijayakumari D, 2-Hydroxy-1-acetonaphthonesemicarbazone as analytical reagent: spectrophotometric determination of some metals, Ph.D., Thesis, S. V. University, Tirupati, India, 1993.

25 Gallego M, Garcia-Vargas M and Valcarcel M, Microchem J., 1979, 24, 143.

26 Rubio S, Gomez-Hens A and Valcarcel M, An Quim Ser B., 1983,79, 72.

27 Garcia-Vargas M, Gallego M and De la Guardia M, Analyst, 1980,105, 965.

28 Mallikarjuna Rao K, Sreenivasulu Reddy T and Brahmaji Rao S, J Indian Inst Sci., 1986, 66, 39.

29 Sah P T and Peoples S A, J Am Pharm Assoc Sci Edn., 1954, 43, 513.

30 Charlot G. and Bezier D, Quantitative inorganic analysis p.623. London: Methuen and Co. Ltd, 1957.

31 Vogel, A. I. A Text Book of Quantitative Inorganic Analysis; $3^{\text {rd }}$ Ed., Longman: London, 1961. 


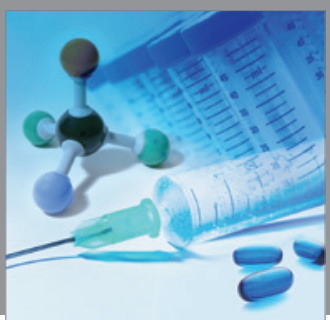

International Journal of

Medicinal Chemistry

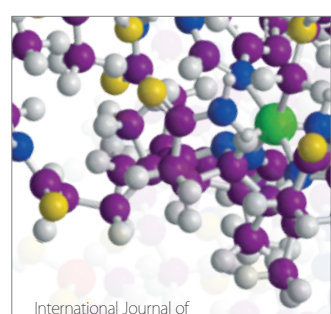

Carbohydrate Chemistry

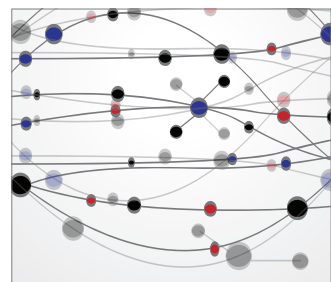

The Scientific World Journal
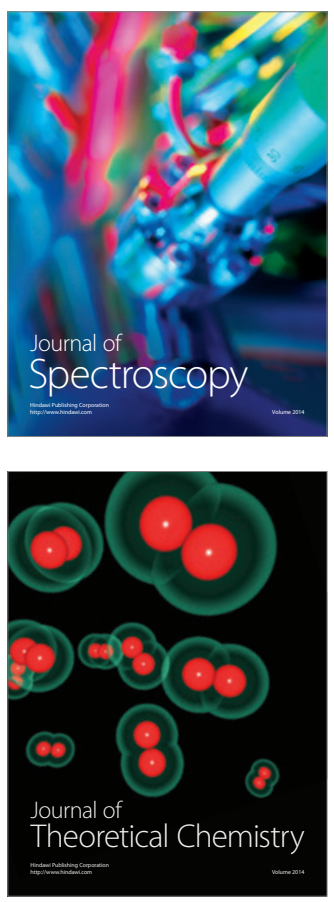
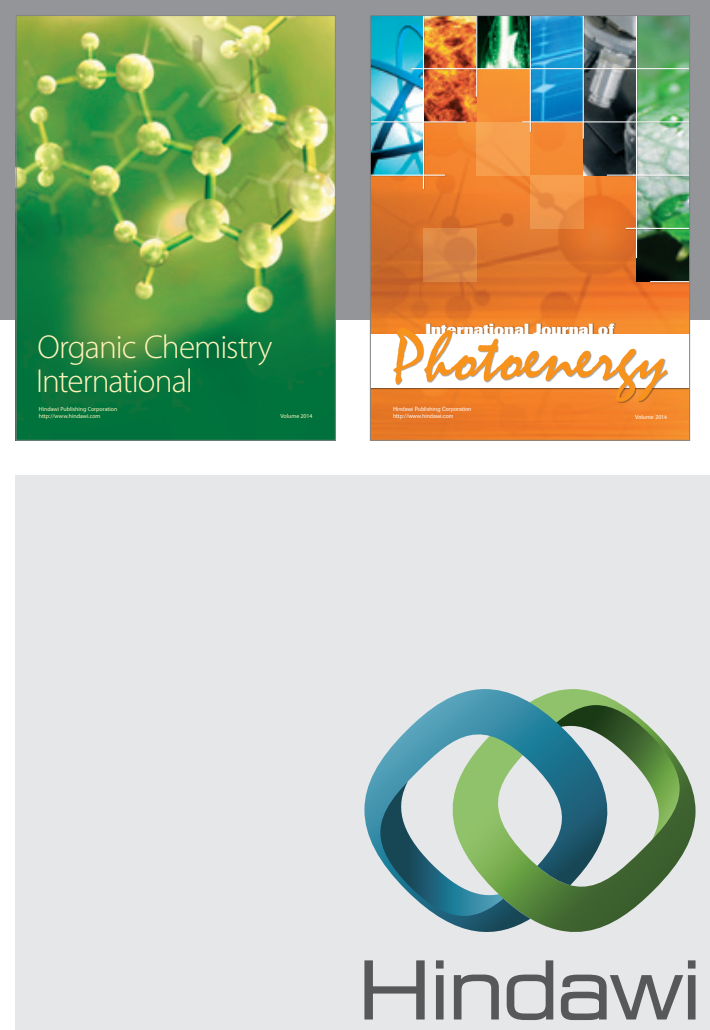

Submit your manuscripts at

http://www.hindawi.com
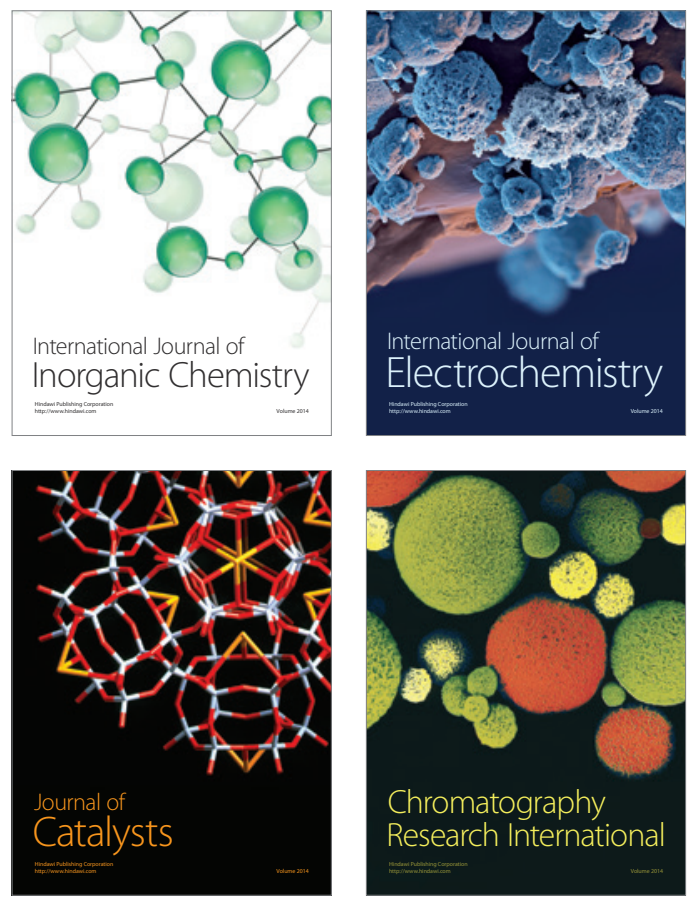
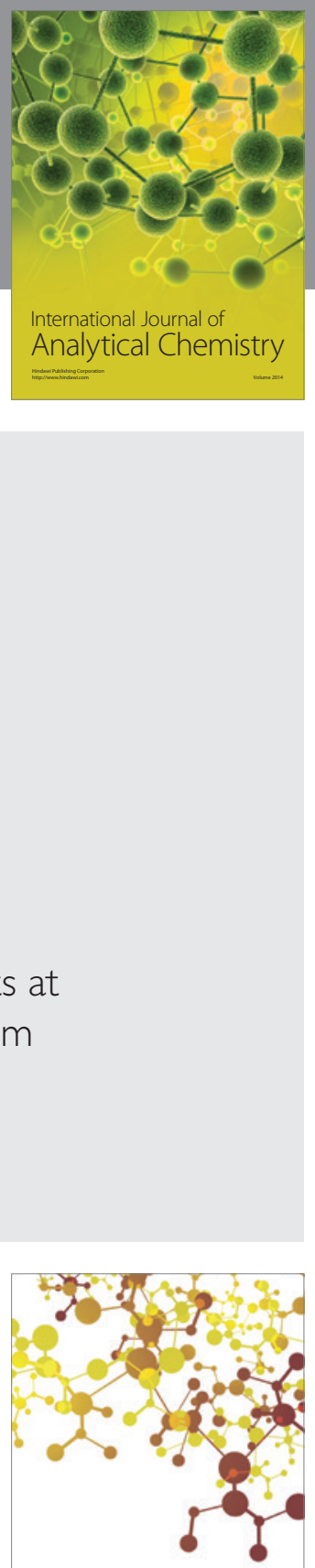

Journal of

Applied Chemistry
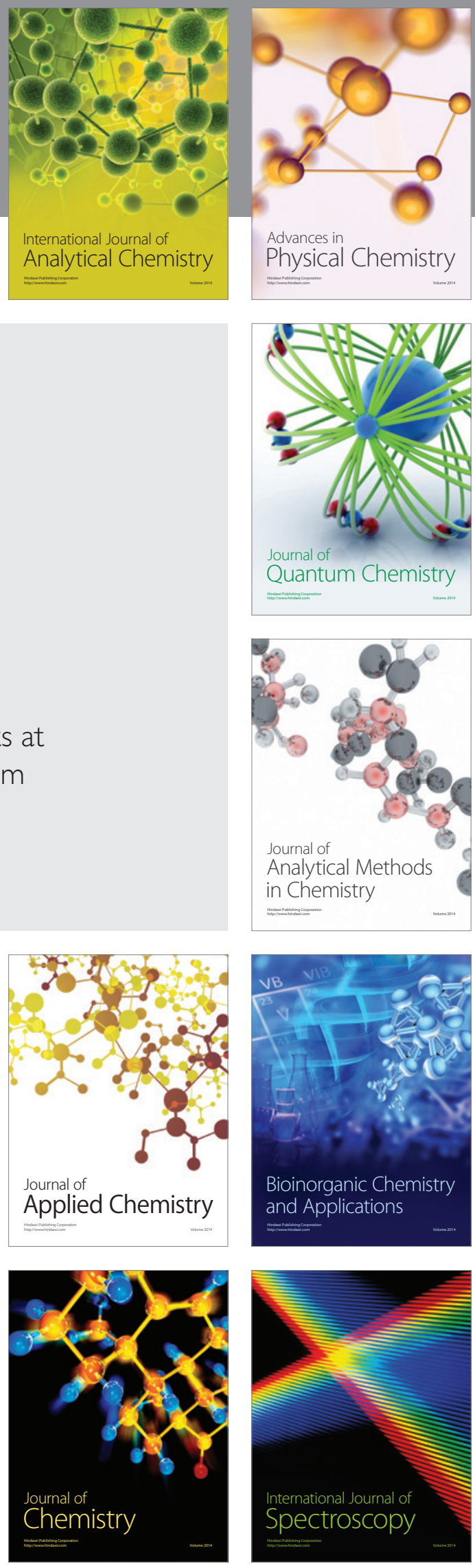